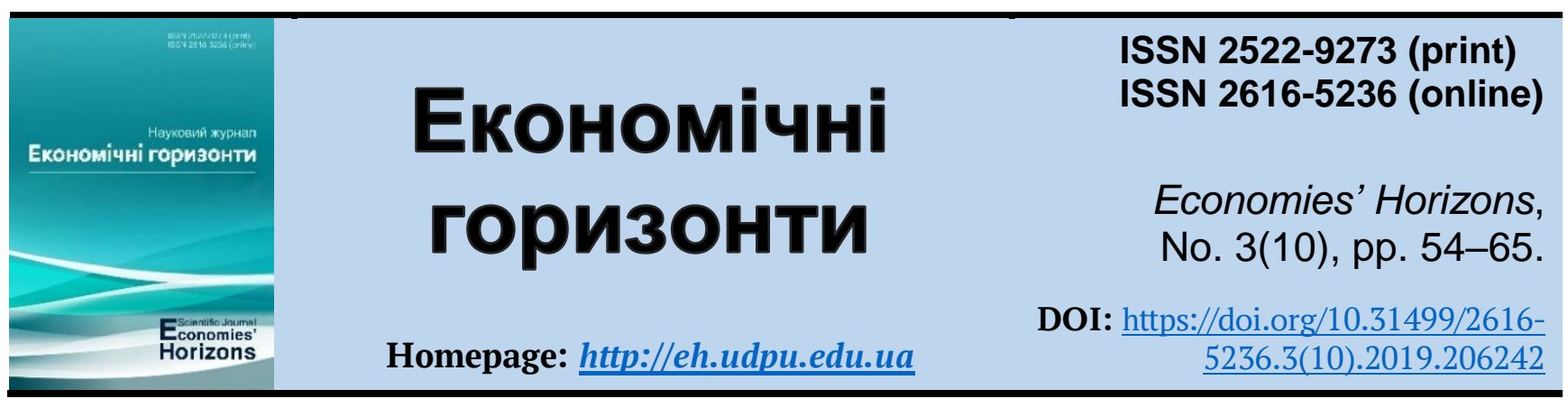

UDC 338.48:001.82

\title{
Methodological algorithms of sustained functioning of tourism and recreation enterprises in clusters
}

\author{
Olena O. Maslihan ${ }^{1}$, Cand. Ec. Sc., Associate Professor \\ Nadiia S. Kampov ${ }^{2}$
}

Received: 17 July 2019

Accepted: 21 August 2019

\begin{abstract}
Maslihan, O. O. and Kampov, N. S. (2019), "Methodological algorithms of sustained functioning of tourism and recreation enterprises in clusters", Economies' Horizons, no. 3(10), pp. 54-65, doi: https://doi.org/10.31499/2616-5236.3(10).2019.206242.
\end{abstract}

\begin{abstract}
It is important to define methodological algorithms of sustained functioning of tourism and recreation cluster actors in parallel to the strategic analysis. Algorithms are basic objects and it forms the basis good description of the methods. Cluster actors, get the perfect solution of urgent problems of a scientific and practical nature by doing everything in accordance with a fixed methodological algorithm (in the context of the task of ensuring the sustained of clusters functioning). It is safe to say, looking at the similarity of algorithms for different spheres of activity, which guide reference and compact subpopulation parameters of the dynamic cluster environment or attractor. On the basis of the foregoing, the purpose of the research is to define the characteristics of the process of methodological algorithmization of financial stability of recreation and tourism cluster's enterprises. Methods. By the study process the following general scientific and concrete methods have been used: comparative, structural, historical (used in describing the classical and transformed break-even model, for rationing of the production of tourism product or tourist services), system-based review techniques and secondary data analysis (used in the optimization of algorithm for calculating the safety margin and creation of a system of methodological algorithm "financial leverage"), generalizations, interpretations, logical (used in determining the assets presentation logic of the cluster actors (in physical terms and in the amount and in monetary and non-monetary forms). Results. On the basis of survey results agreed that, in order to maintain a high level of technological sustainability cluster actors' methodological algorithms to the optimization of technological quality of the tourist product or services of the cluster actors must be selected. This is appropriate on the basis an ongoing monitoring of the level of technological quality of a tourist product or service (compared to produce by competitors). Practical meaning. Monitoring the level of technological quality of a tourist product or service makes it possible to understand, how to get close to the standard. Prospects for further research. The methodological algorithms ensure the sustained functioning of tourism and recreation enterprises in clusters should aim at determining the values of the processing characteristics of the manufacturing process (own and competitors) and identify the directions for their improvement. Individual measurement indicators correspond to each processing characteristics of the manufacturing process. Therefore, these characteristics should be assessed into a comparable form. Namely it based on rating scales and taking into account the mutual influence on the actual competitive rating. To reveal and calculate the mutual influence of processing characteristics (on each other and on
\end{abstract}

\footnotetext{
${ }^{1}$ Mukachevo State University; Associate Professor at the Department of Tourism and Geography; ORCID ID: https://orcid.org/0000-0002-8465-548X; e-mail: O.Maslyhan@mail.msu.edu.ua.

${ }^{2}$ Mukachevo State University; Senior Lecturer at the Department of Tourism and Geography; ORCID ID: https://orcid.org/0000-0003-3661-3899; e-mail:hojsaknad@gmail.com.
} 
Maslihan 0. O., Kampov N.S. Methodological algorithms of sustained functioning of tourism and recreation enterprises in clusters

the actual assessments of competitive position), as a setting for quality home, additional columns of the roof type is formed.

Keywords: cluster; cluster actors; algorithms; attractor; break-even model.

JEL Classification: R11, R58, Z32.

Number of references: 15; number of tables: 6; number of figures: 1; number of formulas: 2.

\title{
Методологічні алгоритми забезпечення сталого функціонування підприємств рекреації та туризму в межах кластерного утворення
}

\author{
Олена Олександрівна Маслиган ${ }^{1}$, к. е. н., доцент \\ Надія Семенівна Кампов ${ }^{2}$
}

Стаття надійшла: 17.07.2019 Стаття прийнята: 21.08.2019

\begin{abstract}
Maslihan O. O., Kampov N. S. Methodological algorithms of sustained functioning of tourism and recreation enterprises in clusters. Економічні горизонти. 2019. № 3(10). C. 54-65. DOI: 10.31499/2616-5236.3(10).2019.206242.
\end{abstract}

Анотація. Поряд із стратегічним аналізом важливим $є$ окреслення методологічних алгоритмів забезпечення сталого функціонування підприємств рекреації та туризму в межах кластерного утворення. Алгоритми є базисними поняттями, формують основу змістового опису методів. Автономний учасник кластеру, зробивши все у відповідності до встановленого методологічного алгоритму за граничних умов задачі щодо забезпечення сталого функціонування у кластері, отримає ідеальне рішення нагальних проблем науково-практичного характеру. Це можна стверджувати, якщо орієнтуватись на подібність алгоритмів різних сфер діяльності, на основі яких формується еталонна компактна підмножина параметрів динамічного кластерного середовища або аттрактор. Виходячи з наведених положень метою дослідження є визначення особливостей процесу методологічної алгоритмізації фінансової стійкості підприємств рекреації та туризму в межах кластерного утворення. Методи. У процесі проведення дослідження використані такі загальнонаукові та конкретні методи: порівняльний, структурний, історичний (при описі класичної та трансформованої моделі беззбитковості, для нормування обсягу виробництва туристичного продукту або надання туристичних послуг), методи системного аналізу та аналізу вторинних даних (при оптимізації алгоритму розрахунку запасу фінансової міцності та формування системи методологічних алгоритмів «фінансового важеля»), узагальнення та інтерпретації, логічний (для визначення логіки представлення активів автономного учасника кластеру за формою та змістом та логіки представлення активів автономного учасника кластеру за змістовністю у грошовій та не грошовій формах). Результати. За результатами дослідження констатовано, що з метою підтримки високого рівня технологічної стійкості автономного учасника кластеру необхідне виділення методологічних алгоритмів оптимізації технологічної якості туристичного продукту або послуг автономного учасника кластеру. Окреслене доцільно на основі постійного моніторингу рівня технологічної якості туристичного продукту або послуги, у порівнянні з тими, що виробляються конкурентами. Практичне значення. Моніторинг рівня технологічної якості туристичного продукту або послуги дозволить зрозуміти, як краще наблизитися до еталону. Перспективи подальщих досліджень. Методологічні алгоритми забезпечення сталого функціонування підприємств рекреації та туризму у межах кластерного утворення мають бути спрямовані на визначення значень технологічних характеристик власного виробничого процесу та виробничого процесу конкурентів, виділення напрямків їх покращення. Кожній технологічній характеристиці виробничого процесу відповідають індивідуальні індикатори виміру. Оцінка окреслених характерис-

\footnotetext{
1 Мукачівський держсавний університет; доцент кафедри туризму i географії; ORCID ID: https://orcid.org/0000-0002-8465-548X; e-mail: O.Maslyhan@mail.msu.edu.ua.

${ }^{2}$ Мукачівський державний університет; старший викладач кафедри туризму і географії; ORCID ID: https://orcid.org/0000-0003-3661-3899; e-mail: hojsaknad@gmail.com.
} 
тик має проводитись до зіставного вигляду. Для врахування та виявлення взаємного впливу технологічних характеристик одна на одну та на фактичний конкурентний рейтинг, як настройка до будинку якості формуються додаткові колони типу крівлі.

Ключові слова: кластер; автономний учасник кластеру; алгоритми; аттрактор; модель беззбитковості.

Кількість джерел: 15; кількість таблищь: 6; кількість рисунків: 1; кількість формул: 2.

\section{Introduction.}

It is important to define methodological algorithms of sustained functioning of tourism and recreation cluster actors in parallel to the strategic analysis. Algorithms are basic objects and it forms the basis good description of the methods. Algorithms are interpreted as some optimality (as they approach the predicted absolute). Actors, get the perfect solution of urgent problems of a scientific and practical nature by doing everything based on fixed methodological algorithm (in the context of the sustained of clusters functioning task). It is safe to say, looking at the similarity of algorithms for different spheres of activity, which guide reference and compact subpopulation parameters of the dynamic cluster environment or attractor (Shcherbak, 2018, p. 31).

A subset of $U$, will be represented by the internal dynamics $f$ the parameters and their internal functions of $\overline{f(U)} \mathrm{C} \cup$. However, all development paths and parameters of functioning of cluster actors will ensure the sustainability assuming that they will pursue (it time) to the standard (Dovba and Soima, 2016, p. 131; Kmit and Dziurii, 2016, p. 65). But in fact, the attractors are understood as (Shcherbak, 2018, p. 31): fixed points (the standards of core indicators), periodically trajectories (the fluctuations of the basic indicators) and well-defined cluster environment (with unsustainable sustained functioning indicators).

The methodological algorithmization process in organizational resilience practice should be aimed at ensuring of its rhythmic. With the technological and financial sustainability this process is closely related. The more financially sustainable and technologically advanced the enterprise is, the better the production capacity of the cluster actors is used.

\section{Literature review.}

Cluster management issues, as a regional management tool, are surrounded by the work I. Dovba and S. Soima (2016), I. Chykarenko
(2012), N. Chala (2012), A. Orlova and M. Buhaieva (2017), A. Chukhno (2010). With this, the analysis of the basic provisions of scientific works leads to the conclusion that in clusters there is structural connection.

Thus, cluster actors (or enterprises) are connected a unified system of close structural interactions. As a result, enterprises, organizations, and institutions get the abilities to work together or complement one another.

During this process it is necessary management of the sustainable of such clusters functioning and their effective management paradigm. Otherwise, such cohesion unravels and the cluster disappears. However, importance of algorithms of sustainable functioning of cluster actors (at the local or regional level) underlines A. Orlova and M. Buhaieva (2017). At the same time, this conclusions haven't been accompanied by detailing of these algorithms.

Thus, notwithstanding the wide range of practices in this field, the problem of specifying instructions for ensuring the sustained of clusters functionality still remain unexplored.

\section{Methodology.}

By the study process the following general scientific and concrete methods have been used:

- comparative, structural, historical (used in describing the classical and transformed break-even model, for rationing of the production of tourism product or tourist services);

- system-based review techniques and secondary data analysis (used in the optimization of algorithm for calculating the financial strength and creation of a system of methodological algorithm "financial leverage");

- generalizations, interpretations, logical used in determining the assets presentation logic of the cluster actors (in physical terms and in the amount and in monetary and nonmonetary forms). 


\section{Research objectives.}

On the basis of the foregoing, the purpose of article is to define the characteristics of the process of methodological algorithmization of financial stability of recreation and tourism cluster enterprises.

\section{Results and discussions.}

The process of methodological algorithmization of financial stability should ensure: profitability, creditworthiness and solvency. Above all, must be generated the algorithm that will ensure secure profitability and potential opportunities of complete and timely liquidation of cluster actors obligations (by break-even models). What is most important is use as a fixed point of the attractor (with the periodic trajectory) of the basis of break-even model. This basis is a breakeven point (under which profits of cluster actors should be zero). Such a point will provide the perfect solution scientific and practical problem, volume-rationing of production of tourist product or tourist services (in physical terms and in amount).

Taking into account the disadvantages of the classic break-even model, it should be optimized and customized to the functional features of recreation and tourism enterprises in the cluster (Table 1).

Table 1. The classical and transform break-even model, for rationing of the production of tourism product or tourist services

\begin{tabular}{|c|c|c|c|}
\hline \multicolumn{2}{|c|}{ The break-even point } & \multirow[b]{2}{*}{ Notation keys } & \multirow{2}{*}{$\begin{array}{c}\text { Weaknesses that make neces- } \\
\text { sary model optimization / } \\
\text { optimization specifics }\end{array}$} \\
\hline model & $\begin{array}{c}\text { General algorithm for } \\
\text { calculating }\end{array}$ & & \\
\hline \multicolumn{4}{|c|}{ The classic model } \\
\hline $\begin{array}{l}\text { Services / } \\
\text { products, } \\
\text { in physical } \\
\text { terms }\end{array}$ & $\begin{array}{l}\mathrm{P}=\mathrm{R}-\mathrm{VC}-\mathrm{FC}=(\mathrm{p} \times \\
\times \mathrm{Q})-(\mathrm{v} \times \mathrm{Q})-\mathrm{FC}=0, \\
\text { in so doing } \\
\mathrm{Q}^{\prime}=\mathrm{F} /(\mathrm{p}-\mathrm{v})\end{array}$ & \multirow{2}{*}{$\begin{array}{l}\mathrm{P} \text { - volume of general profit of tourism en- } \\
\text { terprises; R - revenue from the sale of tour- } \\
\text { ism products or services, UAH; VC - com- } \\
\text { bined variable costs of tourism enterprises; } \\
\text { FC - combined fixed costs of tourism enter- } \\
\text { prises; Q' - break-even point (in physical } \\
\text { terms); } \mathrm{p} \text { - the cost of a service or tourism } \\
\text { product (to satisfy touristic demands); v - } \\
\text { variable costs on unit of evaluation; F - vol- } \\
\text { ume of fixed costs }\end{array}$} & \multirow{2}{*}{$\begin{array}{l}\text { It is anticipated that during the } \\
\text { plan period commodity prices, } \\
\text { required for the production ser- } \\
\text { vices or products, and exercise } \\
\text { price of tourism product and } \\
\text { tourist services is stable, which is } \\
\text { not possible under market condi- } \\
\text { tions; } \\
\text { It is anticipated that the cluster } \\
\text { actors produce one service or ho- } \\
\text { mogeneous range of services. }\end{array}$} \\
\hline $\begin{array}{l}\text { Amount, } \\
\text { UAH }\end{array}$ & $\begin{array}{l}S=F C \times p /(p-v)= \\
=Q^{\prime} \times p .\end{array}$ & & \\
\hline \multicolumn{4}{|c|}{ "Optimized and customized" model } \\
\hline $\begin{array}{l}\text { Services / } \\
\text { products, } \\
\text { in physical } \\
\text { terms }\end{array}$ & $\begin{array}{l}\mathrm{Pi}=\mathrm{Ri}-\mathrm{VCi}-\mathrm{FVi}= \\
=(\overline{\mathrm{pi}} \times \mathrm{Qi})-(\mathrm{vi} \times \mathrm{Qi})- \\
-\mathrm{FVi}=0 \text { in so doing } \\
\mathrm{Q}^{\prime} \mathrm{i}=\mathrm{Fi} /(\mathrm{pi}-\mathrm{vi}) \\
\mathrm{Bi}=\mathrm{f}(\mathrm{t})\end{array}$ & \multirow{2}{*}{$\begin{array}{l}\text { Ri - revenue from the sale of conditionally } \\
\text { similar group of tourist product or services; } \\
\text { VC i - combined variable costs on production } \\
\text { of conditionally similar group of tourist prod- } \\
\text { uct or services of tourist enterprise; FVi - } \\
\text { combined fixed costs of conditionally similar } \\
\text { group of tourist product or services of cluster } \\
\text { actors produced (based on distribution } \\
\text { method); pi - the average price in condition- } \\
\text { ally similar group of tourist product or ser- } \\
\text { vices; Q'i - break-even point in conditionally } \\
\text { similar group of tourist product or services } \\
\text { (in physical terms) ; vi - variable costs on } \\
\text { unit of evaluation (in this case it is condition- } \\
\text { ally similar groups of tourist product or ser- } \\
\text { vices); Fi - volume of fixed costs on produc- } \\
\text { tion of conditionally similar group of tourist } \\
\text { product or services of a tourist enterprise; } \\
\varphi^{\mathrm{p}}-\text { the distribution base as universal magni- } \\
\text { tude, which defines the distributional propor- } \\
\text { tion for FVi; } \varphi \mathrm{i}^{\text {, }} \text { - the overall share of fixed } \\
\text { costs, who are subject to distribution. }\end{array}$} & \multirow{2}{*}{$\begin{array}{l}\text { The specificity of manufacture } \\
\text { of tourist product is quite dy- } \\
\text { namic. It depends on the needs of } \\
\text { tourists and the destination (at- } \\
\text { tractions, where the tourist re- } \\
\text { ceives services). They can be al- } \\
\text { located by the method of similar- } \\
\text { ity of service complexes. This, } \\
\text { for its part, forms the specificity } \\
\text { of costs, which can be fixed (by } \\
\text { specific types of tourist prod- } \\
\text { ucts). } \\
\text { In optimized and customized } \\
\text { there should be differentiation of } \\
\text { tourist products (by condition- } \\
\text { ally similar groups). Naturally, } \\
\text { FVi should be distributed be- } \\
\text { tween groups of conditionally } \\
\text { similar tourist products or ser- } \\
\text { vices cluster actors (in accord- } \\
\text { ance with distribution base). }\end{array}$} \\
\hline $\begin{array}{l}\text { Amount, } \\
\text { UAH }\end{array}$ & $\begin{array}{l}\mathrm{S}_{\mathrm{i}}=\mathrm{FVi} \times \overline{\mathrm{pi}} /\left(\overline{\mathrm{pi}}-\mathrm{V}_{\mathrm{i}}\right)= \\
=\mathrm{Q}_{\mathrm{i}}^{\prime} \times \overline{\mathrm{pi}} \\
\mathrm{FVi}=\varphi \mathrm{p} \times \\
\times \mathrm{FVcombined}, \text { in so } \\
\text { doing } \\
\varphi^{\mathrm{p}}=\frac{\varphi \mathrm{i}}{\varphi \text { aggr }}\end{array}$ & & \\
\hline
\end{tabular}

Source: formed by the author based on (Klepikova and Silvestrova, 2015, pp. 167-168). 
FVi should be determined by distribution between conditionally similar group of tourist product and services of cluster actors in the model of break-even.

For volume-rationing of production of a product or services the actors are being implemented an additional value - the distribution base $\left(\varphi^{\mathrm{p}}\right)$.

Additional value can be chosen: the total amount of salary costs the laborers who shall be directly produce tourism services; the share of income of conditionally similar groups of tourist product or services.

The special character of ensuring the sustained of cluster functionality will be based on excess of actual level of providing tourism services over fixed point of attractor (or break-even point) (Yushchenko and Kuslii, 2015, pp. 79-80).

In such circumstances, financial safety will be provided (or C). It is a guarantee of profitability, it identified as the arithmetic mean of individual values conditionally similar tourist product or services $\left(\mathrm{Ci}\right.$ ), on the basis of $\mathrm{Q}^{\prime} \mathrm{i}$ та Si (according to optimized algorithms presented in Table 2).

Table 2. Optimized algorithms of financial strength calculating

\begin{tabular}{|c|c|c|c|}
\hline \multicolumn{3}{|c|}{ The algorithm of financial strength calculating } & \multirow[b]{2}{*}{ Notation keys } \\
\hline \multicolumn{2}{|c|}{$\begin{array}{l}\text { the differential fixed point in the cluster } \\
\text { attractor }\end{array}$} & $\begin{array}{l}\text { the arithmetic mean } \\
\text { of fixed point (in } \\
\text { cluster's attractor) }\end{array}$ & \\
\hline in amount & in physical terms & & \\
\hline $\begin{array}{l}\mathrm{C} i=\frac{B i-S i}{B i+\Gamma \mathrm{C}} \times 100 \% \\
\text { in so doing } \\
\mathrm{Bi}=\mathrm{f}(\mathrm{t})\end{array}$ & $\mathrm{Ci}=\frac{\mathrm{Pni}-\mathrm{Q}^{\prime} \mathrm{i}}{\mathrm{Pni}} \times 100 \%$ & $\overline{\mathrm{C}}=\frac{\sum \operatorname{Ci} 1+\cdots+\operatorname{Cin} n}{n}$ & $\begin{array}{l}\text { ditionally similar group of tourist prod- } \\
\text { uct or services; } \bar{C} \text { - the average value of } \\
\text { financial strength of cluster actor. }\end{array}$ \\
\hline
\end{tabular}

Source: formed by the author based on (Klepikova and Silvestrova, 2015, pp. 167-168, Yushchenko and Kuslii, 2015, pp. 79-80)

In volume-rationing of production of a tourist product or services (based on a model of break-even) it is important to use reasonable baseline of the $\mathrm{Bi}$. The norm must be real. For this purpose, it is reasonable to use the most accurate method of establishing a certain future value. In particular, techniques of time series extrapolation, in conjunction with techniques of change in the average towards growth rate of similar groups of tourist product or services. Thus, the forecasting of $\mathrm{Bi}$ is based on trends-functions (by selecting of curves, most accurately reflecting possible revisions in time), taking into account the influence of all factors. These trends-functions determined by the algorithm:

$$
\mathrm{Bi}=\mathrm{f}(\mathrm{t}),
$$

where $\mathrm{V}$ - possible volume of provision of conditionally similar groups of tourist product or services;

$\mathrm{t}$ - period of research (or planning).
Based on, curve equation values will be compiled (linear, exponential, logarithmic, polynomial, power) and the forecast accuracy is evaluated (based on approximation value or $\mathrm{R}^{2}$ ). The dynamics of changes in which the approximation value will be close to 1 is expedient. If it is not possible to set the type of curve to identify trends of the $\mathrm{Vi}$, it is appropriate to apply the method of modified average (relative to the growth rate of conditionally similar types of tourist product or services). However, should be constructed the trend "moving average".

It is positive that the use of a point of break-even as attractor's fixed points creates conditions for the implementation of "financial leverage" (FL). Financial leverage is required as an auxiliary methodological algorithm for ensuring guaranteed profitability of cluster actors (by conditionally similar groups of tourist product, services or in general).

This methodological algorithm is based on the assessment of the relationship between 
fixed and variable costs. The algorithm provides that the rising fixed costs in transaction costs change the amount of operating profit of the of cluster actors. This method identifies the quality problems and distributes them to key categories that affecting the services or product profile:

1) Increase in operating profit in relation to the volume of tourist products rendered, or services rendered (by conditionally similar groups or in general);

2) Greater sensitivity of operating profit to changes in cash flows.

Naturally, the sharp decline in in the volume of services rendered can increase the domino effect risk, related to negative financial strength. In this case, the FL is determined according to the optimized algorithm:

$$
\mathrm{FLi}=\frac{\mathrm{FVi}}{\mathrm{VCi}} \text { or } \overline{\mathrm{FL}}=\frac{\sum \mathrm{FLi} 1+\cdots+\mathrm{FLi} 2}{n},
$$

where $n$ - number of conditionally similar groups of tourist products or services of cluster actors produced;

FLi1 + - + FLi2 - operating lever of conditionally similar groups of tourist products or services;

$\overline{\mathrm{FL}}$ - total operating lever of cluster actors.
Well, seeing as the formation of actors' solvency and creditworthiness is possible only with balanced recruitment of credit funds needed to be forged such capital structure that will ensure increased profits in the form of surplus value. Thus, the cluster actors creditworthiness and solvency depends on the capital structure. It is appropriate to allocate as an attractor's fixed point (from a periodic trajectory) a two-level of financial leverage and a matrix of solvency forms. At the same time, the two-level of financial leverage, as an attractor's fixed point, will operate subject to availability of loan capital in the liability structure of the actors.

There are concerns, which as this balance sheet items grows, the financial burden increases. It's the kind of thing that could have negative effects on solvency (effect FL-) but this increases own capital's cost-effectiveness (effect FL+).

In any case, these points (according to the effects) can be a remedy, for solutions to the problems of operational support of values of significant elements of capital of the cluster actors. The system of methodological algorithms of financial leverage will include search for an ideal solution to problems in the capital structure optimization of the cluster actors (Table 3).

Table 3. The system of methodological algorithm of financial leverage

\begin{tabular}{|c|c|c|c|}
\hline The effect & $\begin{array}{c}\text { Specifics of address the } \\
\text { problem on capital structure opti- } \\
\text { mization }\end{array}$ & $\begin{array}{l}\text { The general } \\
\text { algorithm for } \\
\text { calculating }\end{array}$ & Notation keys \\
\hline $\begin{array}{l}\text { positive ef- } \\
\text { fect }(\mathrm{FL}+)\end{array}$ & $\begin{array}{l}\text { The use of loan capital integrates the } \\
\text { growth of financial leverage. } \\
\text { Thus, under conditions of stable, en- } \\
\text { sures more efficient own capital uses } \\
\text { (that is reflected in the growth of its } \\
\text { cost-effectiveness). }\end{array}$ & $\begin{array}{l}\qquad \mathrm{FL}+=\left(\frac{L C}{O C}\right)(\mathrm{EP}- \\
\text { IR })(1-\tau) \\
\text { This algorithm is based } \\
\text { on regulating the finan- } \\
\text { cial leverage in the cap- } \\
\quad \text { ital structure }\end{array}$ & $\begin{array}{l}\text { EP - the cost-effectiveness (\%),which } \\
\text { is based on amount of Profit Before In- } \\
\text { terest and Tax; } \tau \text { - income tax rate; IR } \\
\text { - interest rates on the credit (for the } \\
\text { period), \%; (EP - IR) - the diff of fi- } \\
\text { nancial leverage, growth which reduces } \\
\text { risk of non-repayment of credits; } \frac{L C}{O C}- \\
\text { the own and loan capital. }\end{array}$ \\
\hline $\begin{array}{l}\text { negative im- } \\
\text { pact (FL -) }\end{array}$ & $\begin{array}{l}\text { The inverse value toward FL }+ \text {. } \\
\text { The effect related to the declining the } \\
\text { solvency of cluster actors, that gener- } \\
\text { ates a risk of untimely liquidation of } \\
\text { obligations in the next reporting pe- } \\
\text { riod. } \\
\text { This risk is integrated into the event of } \\
\text { asset enhancement (in cash) and in- } \\
\text { creased borrowing (OC). }\end{array}$ & $\begin{array}{l}\mathrm{FL}-=\left(\frac{M f}{N O n M f}\right) \text { equal to } \\
\qquad 0<\frac{L C}{O C}<\mathrm{FL}-. \\
\text { Based on the regulation } \\
\text { of financial leverage in } \\
\text { the asset structure. }\end{array}$ & $\begin{array}{l}\text { Mf/NonMf - asset enhancement of the } \\
\text { cluster actors (in monetary and non- } \\
\text { monetary forms) that determination by } \\
\text { matrix of solvency forms. }\end{array}$ \\
\hline
\end{tabular}

Source: formed by the author based on (Dudar and Vakulchyk, 2018, pp. 878-882). 
Thus, the operational support of optimal for own capital with a sufficient level of solvency of the cluster actors is based on respect the following inequality: FL $+\leq \mathrm{FL}-$.

For the attractor, a limit should establish, at which inequality is unobserved, and the actors will not have sufficient maintain asset to keep solvency (Shcherbak, 2018, p. 31-35). Thus, preference should be given to accumulation of maintain asset. At the same time, to set the level of financial leverage should be used a matrix of solvency forms. That should be done on such methodology (Fesun, 2015, pp. 104108):

1) Sets the amount of all assets (A) of cluster actors in two basic areas, namely in the form (in terms of the liquidity levels) and on the content (in terms of the total content). At the same time, the identification the assets form is carried out broken down by in monetary (Mf) and non-monetary forms (NonMf) (Table 4).

Table 4. Assets presentation logic of the cluster actors (in form and on the content)

\begin{tabular}{|l|l|l|}
\hline $\begin{array}{c}\text { In the form } \\
\text { (in terms of } \\
\text { the liquid- } \\
\text { ity levels) }\end{array}$ & On the content (in terms of the total content). & $\begin{array}{c}\text { The way of identifying of sol- } \\
\text { vency forms }\end{array}$ \\
\hline $\mathrm{m}$ & $\begin{array}{l}\text { Cash payments, funds in the current Client's account } \\
\text { and collection of money (collection of money pro- } \\
\text { ceeds with the opportunity to credit them to the Cli- } \\
\text { ent's account with the bank); short-term financial in- } \\
\text { struments (including highly liquid). }\end{array}$ & $\begin{array}{l}\text { This a means of payment or } \\
\text { funds that is converted into } \\
\text { means of payment (these funds } \\
\text { are characterized by low risk of } \\
\text { depreciation). }\end{array}$ \\
\hline non-m & $\begin{array}{l}\text { Noncurrent assets; stocks of raw materials and sup- } \\
\text { plies or fuel, necessary for provision of tourism ser- } \\
\text { vices; other stocks and current assets (OS); receiva- } \\
\text { bles; deferred charges }\end{array}$ & $\begin{array}{l}\text { These assets are characterized } \\
\text { by certain degree of liquidity. } \\
\text { These assets aren't a real means } \\
\text { of payment at the moment. }\end{array}$ \\
\hline
\end{tabular}

Source: formed by the author based on (Fesun, 2015, pp. 104-108).

2) The identification of property $(\mathrm{Pr})$ of the cluster actors on the basis of content (by ownership), from the debt/equity perspective, in parallel identification: own capital in monetary and non-monetary forms (OCm та OCnon-m) and loan capital in monetary and nonmonetary forms (LCm та LCnon-m) (Table 5).

\section{Table 5. Property presentation logic of the cluster actors on the content (in monetary and} non-monetary forms)

\begin{tabular}{|c|c|c|}
\hline $\begin{array}{l}\text { In the } \\
\text { form }\end{array}$ & On the content (total contents by accessory) & $\begin{array}{c}\text { The specifics of determining the solvency } \\
\text { forms }\end{array}$ \\
\hline CLm & $\begin{array}{l}\text { ash credit and other debt and interest on } \\
\text { bans }\end{array}$ & $\begin{array}{l}\text { Monetary liabilities, which have emerged } \\
\text { because hadn't been advanced in assets. }\end{array}$ \\
\hline $\begin{array}{l}\text { CLnon- } \\
\mathrm{m}\end{array}$ & $\begin{array}{l}\text { Commercial credit; advance payment and } \\
\text { other obligations, promissory notes received, } \\
\text { salary obligations (in working hours) and } \\
\text { other; restitutionary obligations }\end{array}$ & $\begin{array}{l}\text { The total amount of short-term and long- } \\
\text { term accounts payable, credits and loans, } \\
\text { that had been advanced in assets }\end{array}$ \\
\hline
\end{tabular}

Source: formed by the author.

The proposed methodology (using the overlay method) allows determining forms of the liquidity and content of asset of the cluster actors. Also the content of assets (by the ownership right) can be identified this methodol- ogy conducted. In particular, in two-level matrix dependencies of a logical value of the linked evaluated expression in the actors's structure of property are formed (Fig. 1). 
Maslihan O. O., Kampov N. S. Methodological algorithms of sustained functioning of tourism and recreation enterprises in clusters

\begin{tabular}{|c|c|c|c|c|c|c|c|c|c|}
\hline \multirow{2}{*}{\multicolumn{4}{|c|}{$\begin{array}{l}\text { the statistical format of cluster actors } \\
\text { property }\end{array}$}} & \multicolumn{6}{|c|}{ the dynamic / step values format of cluster actors property } \\
\hline & & & & \multirow[t]{2}{*}{ liquidity } & \multicolumn{5}{|c|}{$\begin{array}{c}\text { total contents by accessory (the dynamic / step values } \\
\text { format) }\end{array}$} \\
\hline $\begin{array}{c}\text { by the } \\
\text { owner- } \\
\text { ship right }\end{array}$ & $\begin{array}{l}\text { own } \\
\text { capital } \\
\text { (OC) }\end{array}$ & $\begin{array}{c}\text { loan } \\
\text { capital } \\
\text { (LC) } \\
\text { loan } \\
\text { capital }\end{array}$ & $\begin{array}{l}\text { Itera- } \\
\text { tive } \\
\text { prop- } \\
\text { erty } \\
\text { valua- } \\
\text { tion }\end{array}$ & & $\begin{array}{l}\text { Debit } \\
\text { balance } \\
\text { at the } \\
\text { begin- } \\
\text { ning of } \\
\text { the pe- } \\
\text { riod }\end{array}$ & $\begin{array}{c}\text { OC } \\
\text { (growth } \\
\text { rate and } \\
\text { step val- } \\
\text { ues) }\end{array}$ & $\begin{array}{c}\text { LC } \\
\text { (growth } \\
\text { rate and } \\
\text { step val- } \\
\text { ues) }\end{array}$ & \multirow{2}{*}{$\begin{array}{l}\text { Debit } \\
\text { bal- } \\
\text { ance at } \\
\text { the } \\
\text { end of } \\
\text { the pe- } \\
\text { riod }\end{array}$} & \multirow{2}{*}{$\begin{array}{l}\text { Iterative } \\
\text { step val- } \\
\text { ues } \pm \Delta\end{array}$} \\
\hline \multirow[t]{2}{*}{$\begin{array}{l}\text { non-mon- } \\
\text { etary } \\
\text { forms }\end{array}$} & \multirow[t]{2}{*}{$\begin{array}{c}\text { OC- } \\
\text { non-m }\end{array}$} & \multirow[t]{2}{*}{$\begin{array}{l}\text { LCnon- } \\
\text { m }\end{array}$} & \multirow{5}{*}{$\begin{array}{c}\mathrm{OCm}+ \\
\mathrm{LCm}+\mathrm{L} \\
\text { Cnon- } \\
\text { m+OC- } \\
\text { non-m }\end{array}$} & $\begin{array}{l}\text { Credit bal- } \\
\text { ance at the } \\
\text { beginning of } \\
\text { the period }\end{array}$ & $\begin{array}{l}\text { Assets } \\
(\mathrm{A}) 0\end{array}$ & $\begin{array}{l}\text { at the } \\
\text { begin- } \\
\text { ning of } \\
\text { the pe- } \\
\text { riod }\end{array}$ & $\begin{array}{l}\text { at the } \\
\text { begin- } \\
\text { ning of } \\
\text { the pe- } \\
\text { riod }\end{array}$ & & \\
\hline & & & & $\begin{array}{l}\text { non-mone- } \\
\text { tary forms }\end{array}$ & $\begin{array}{c}\text { Assets } \\
\text { non-m0 }\end{array}$ & $\begin{array}{c}\text { Step } \\
\text { values }\end{array}$ & $\begin{array}{c}\text { Step } \\
\text { values }\end{array}$ & $\begin{array}{c}\text { Assets } \\
\text { m } 1\end{array}$ & $\begin{array}{l}\text { Step val- } \\
\text { ues }\end{array}$ \\
\hline $\begin{array}{l}\text { monetary } \\
\text { forms }\end{array}$ & $\mathrm{OCm}$ & $\mathrm{LCm}$ & & $\begin{array}{l}\text { monetary } \\
\text { forms }\end{array}$ & $\begin{array}{l}\text { Assets } \\
\mathrm{m} 0\end{array}$ & $\begin{array}{c}\text { Step } \\
\text { values }\end{array}$ & $\begin{array}{c}\text { Step } \\
\text { values }\end{array}$ & $\begin{array}{l}\text { Assets } \\
\text { m } 1\end{array}$ & $\begin{array}{l}\text { Step val- } \\
\text { ues }\end{array}$ \\
\hline \multirow{2}{*}{$\begin{array}{l}\text { Iterative } \\
\text { statistical } \\
\text { valuation }\end{array}$} & \multirow{2}{*}{$\begin{array}{l}\text { OC- } \\
\text { non-m } \\
+ \text { OCm }\end{array}$} & \multirow{2}{*}{$\begin{array}{l}\text { LCbob- } \\
\mathrm{m}+\mathrm{LC} \\
\mathrm{m}\end{array}$} & & \multicolumn{2}{|c|}{$\begin{array}{l}\text { Credit balance at the } \\
\text { end of the period }\end{array}$} & $\begin{array}{l}\text { the end } \\
\text { of the } \\
\text { period }\end{array}$ & $\begin{array}{l}\text { the end } \\
\text { of the } \\
\text { period }\end{array}$ & $\begin{array}{l}\text { Assets } \\
\mathrm{m} 1\end{array}$ & \multirow[t]{2}{*}{$\begin{array}{l}\text { Step val- } \\
\text { ues }\end{array}$} \\
\hline & & & & \multirow{2}{*}{\multicolumn{2}{|c|}{$\begin{array}{c}\text { OC }- \text { Anon-m }=\text { Am - } \\
\text { - LC, Am > LC and OC } \\
>\text { Anon-m }\end{array}$}} & $\Delta \mathrm{OCm}$ & $\Delta \mathrm{LMm}$ & & \\
\hline $\begin{array}{l}\text { money } \\
\text { capital } \\
(\mathrm{MC})^{*}\end{array}$ & \multicolumn{3}{|c|}{ OCm -LCnon-m } & & & $\begin{array}{l}\text { OC - } \\
\text { Anon-m }\end{array}$ & $\mathrm{Am}-$ & & \\
\hline
\end{tabular}

Fig. 1. Matrix of solvency forms of the cluster actors

* Positive money capital provides a guaranteed solvency. In doing so, is submitted that, the largest share of such capital is formed with the support of cluster actors that involve arrangements regulate the ratio Am> LC or OC > Anon-m

Source: formed by the author

Eventually, these dependencies summarizes in balance harmonized data, which are presented in:

1) In statistical format. The actors's property is identified by a liquidity with an illustration of other relationships in its structure, namely, in the cross-section LCnon-m/OCnon- $\mathrm{m}$ and $\mathrm{LCm} / \mathrm{OCm}$ (at the beginning and end of the reporting or planning period);

2 ) In dynamic format. The property of actors's is identified total contents by accessory, with a focus on step values of LCnon-m/OCnon-m та LCm/OCm (or $\Delta \mathrm{LCnon-m/ \triangle OCnon-}$ $\mathrm{m}$ and $\Delta \mathrm{LCm} / \Delta \mathrm{OCm})$.

If, in the preparation process of matrix of solvency forms of the cluster actors, the value of money capital is negative, structural optimization of the value of property in non- monetary terms are necessary. This is done through an expanded system of trigger, the structure of which is systematized in Table 6.

Particular attention should be given to the structure of assets and liabilities in non-monetary form. The structure of assets and liabilities in non-monetary form has the greatest effect on: the nature of the exchange distribution and financing transactions; the nature of solvency and creditworthiness. Through Wilson's and other optimization model it is possible the managing of assets and liabilities structure. For the managing of the financial resources it is possible to use Miller-Orr model (this model takes into account chaotic changes in financial resources balances to the moment when reaching certain thresholds) (Maslyhan, 2016, pp. 408-413). 
Table 6. The expanded system of trigger optimization of structure of assets of cluster actors

\begin{tabular}{|c|c|c|c|c|c|}
\hline $\begin{array}{c}\text { The system of } \\
\text { trigger }\end{array}$ & \multicolumn{5}{|c|}{ The optimized algorithm for trigger calculating } \\
\hline \multicolumn{6}{|c|}{ assets } \\
\hline \multirow[t]{4}{*}{$\begin{array}{l}\text { stocks of raw } \\
\text { materials and } \\
\text { supplies or fuel, } \\
\text { (Based on the } \\
\text { Wilson model) }{ }^{1}\end{array}$} & \multirow[t]{4}{*}{$\begin{array}{l}\text { on condition } \\
\text { that prices } \\
\text { constant } \mathrm{C}^{\mathrm{w}}(\mathrm{q}) \\
=\frac{C s D}{Q}+ \\
\frac{1}{2} c 1 T q \text { where } \\
\text { the optimal } \\
\text { volume of de- } \\
\text { liveries or } q_{0}^{w} \\
\text { is: } q^{w} \sqrt{\frac{2 C s D}{c 1 T}}\end{array}$} & \multirow{4}{*}{\multicolumn{2}{|c|}{$\begin{array}{l}\text { on condition that prices } \\
\text { changes }{ }^{1} \text { : } \\
\mathrm{Cw}(\mathrm{q})=\frac{1}{2} \times Q \times c 1 \times \\
\frac{R Z}{100} \mathrm{C} 0<\mathrm{Cw}(\mathrm{q}) \leq Q \times \mathrm{ma} \\
R Z \text { - includes inventory } \\
\text { carrying costs. } \\
\qquad \mathrm{Cw}(\mathrm{q})=\frac{1}{2} \times Q \times C 1 \\
\quad \times\left(1-\frac{\epsilon \mathrm{C} 1}{100}\right) \\
Q x<\mathrm{Cw}(\mathrm{q}) \leq Q x 2 \text { on } \\
\text { condition that Parcel Prices } \\
\text { is } \mathrm{C} 1 \times \frac{\epsilon \mathrm{C} 1}{100} \\
\mathrm{Cw}(\mathrm{q})=\frac{1}{2} \times Q \times C 1 \times \\
\quad\left(1-\frac{\epsilon \mathrm{C} 1(i-1)}{100}\right) \\
Q x(i-1)<\mathrm{Cw}(\mathrm{q}) \leq Q x i \\
\text { on condition that procure- } \\
\text { ment volume is: } Q x(i-1)\end{array}$}} & \multirow{4}{*}{$\begin{array}{l}\text { on condition that tar- } \\
\text { iffs for transport is } \\
\text { flexible and depends on } \\
\text { the number of transport } \\
\text { cargo (that effect on } \\
\text { transport costs) } \\
\text { Cw(q) } \\
=\frac{1}{2} \times Q \times C 1 \times \frac{R Z}{100} \\
+C \text { chan } \times \frac{D}{Q}+\tau \times \mathrm{D} \\
\text { where the optimal vol- } \\
\text { ume of deliveries or } q_{0}^{w} \\
\text { is: } \\
q_{0}^{w}= \\
\sqrt{\frac{2 \times(\text { Cзмiн }+B \text { Tp.ц }) \times D}{100}} \times c 1 \\
\text { on condition that this } \\
\text { amount of cost c1, cS } \\
\text { and transport costs - } \\
\tau \times D\end{array}$} & \multirow{3}{*}{$\begin{array}{l}\text { on condition that Parcel } \\
\text { Prices is constant and de- } \\
\text { pends on the level of infla- } \\
\text { tion (therefore, advanta- } \\
\text { geous purchase a large } \\
\text { amounts of stocks): } \\
\text { Cw }(\mathrm{q})=\Delta Q \times c 1 \times \\
\frac{i}{100<0} \text { де: } \\
\quad q_{0}^{w}=Q \text { opt } \sqrt{\frac{1}{1-\frac{i}{R Z}}} \\
\text { If C increased on margin } \\
(\mathrm{M}): \\
\mathrm{C} w(q)=(Q \text { opt }-Q \text { inf }) \\
\times \mathrm{C} 1 \frac{i}{100} \text { in so doing } \\
q_{0}^{w} \\
\qquad\end{array}$} \\
\hline & & & & & \\
\hline & & & & & \\
\hline & & & & & $=$ Qopt $\times \sqrt{1+\frac{\mathrm{U} \times \mathrm{i}}{R Z \times 100}}$ \\
\hline $\begin{array}{l}\text { The sum of Re- } \\
\text { serves }\end{array}$ & \multicolumn{5}{|c|}{$\mathrm{R}=(\mathrm{N} \times$ one-day sum of reserves $)+\mathrm{Ss}+\mathrm{Ts}$} \\
\hline $\begin{array}{l}\text { Accounts receiva- } \\
\text { ble }^{3}\end{array}$ & \multicolumn{5}{|c|}{ Accounts receivabl $=\frac{\mathrm{PC} \times \operatorname{cost} / \text { price } \times(\overline{S D}+\overline{I R})}{360}$} \\
\hline $\begin{array}{l}\text { a means of pay- } \\
\text { ment }^{6}\end{array}$ & \multicolumn{2}{|c|}{$\begin{array}{l}\text { The managing of the fi- } \\
\text { nancial resources should } \\
\text { be carried out based on the } \\
\text { erratic fluctuation range } \\
\text { between the maximum and } \\
\text { minimum limits of bal- } \\
\text { ance. This erratic fluctua- } \\
\text { tion ranges defined by an } \\
\text { algorithm: } \\
\text { MC } \frac{o}{\mathrm{M}}=3 *\left(\frac{3}{4} \times \frac{\beta \times \sigma^{2}}{\mathrm{r}}\right)^{1 / 3}\end{array}$} & \multicolumn{2}{|c|}{$\begin{array}{l}\text { When the upper bound limit is } \\
\text { reached } \mathrm{MC} \frac{\max }{\min } \text { the financial resources bal- } \\
\text { ance of limit is converted to in securities or } \\
\text { placing it to deposit accounts, at an amount, } \\
\text { essential in alleviating of the financial re- } \\
\text { sources from the } \mathrm{MC} \frac{\mathrm{max}}{\min } \text { level to level } \\
\mathrm{MC} \frac{\text { opt }}{\min } \text {. in so doing } \mathrm{MC} \frac{\max }{\min } \text { is determined by } \\
\text { algorithm: } \\
\mathrm{MC} \frac{\mathrm{max}}{\min }=\mathrm{MC} \frac{\text { opt }}{\min }-\mathrm{MC} \frac{\mathrm{mim}}{-}\end{array}$} & $\begin{array}{l}\text { While lowering the finan- } \\
\text { cial resources balance to the } \\
\text { lowest possible bound } \mathrm{MC} \\
\frac{\mathrm{min}}{-} \text { is carried out selling of } \\
\text { securities or return } \\
\text { money from the deposit on } \\
\text { the amount needed to } \\
\text { achieve the MC } \frac{o p t}{\mathrm{~min}} \text {. }\end{array}$ \\
\hline \multicolumn{6}{|c|}{ liabilities } \\
\hline $\begin{array}{l}\text { short-term } \\
\text { credit }^{4}\end{array}$ & \multicolumn{5}{|c|}{$\begin{array}{l}\text { cost of services production (upper bound limit) } \\
\text { Short-term credit } 1 \text { = Csp - NWCp - CPpt }-\min _{\text {so. }}\end{array}$} \\
\hline $\begin{array}{l}\text { long-term } \\
\text { credit }^{5}\end{array}$ & \multicolumn{5}{|c|}{$\begin{array}{l}\text { calculation of net working capital based on its purpose (upper bound limit) } \\
\text { Long-term credit } 1 \text { = credit funding - target credit funding }\end{array}$} \\
\hline
\end{tabular}

* Notation keys: ${ }^{1}$ triggers for stocks of raw materials and supplies: $D$ - demand for services for the period $T ; c S-$ the cost of deliveries, with volume $Q, ; c 1$ - cost of stock units for the period $T ; \epsilon$ - price discount in percentage on the price base; C - Parcel Prices; Qxi - purchase amount with minimal $\epsilon ; \mathrm{C}_{\text {chan }}$ - one purchase order costs; $\tau$ - carrier fares per unit of cargo, regarding the $\mathrm{D} ;{ }^{2}$ triggers for sum of reserves (RS): $\mathrm{N}$ - norm for ongoing storage, in days; one-day sum of reserves - one-day levels of stocks of raw materials and supplies; Ss/Ts - the plan levels of season stocks and target stocks; PC - the planning credit marketing of services of cluster actors; cost/price - this is the result of the ratio cost/price factors, expressed by number of infinite; $\overline{S D}$ - average period for service delivery, days; $\overline{I R}$ - average time of instalment repayments, days; ${ }^{4}$ triggers for short-term credit to finance of service production: Csp - the planned total cost of the tourist services production; NWCp - projected amounts of net working capital; CPpt - the plan value of accounts payable of product transactions; $\min _{\text {so }}$ - the minimum plan value of current settlement obligations; ${ }^{5}$ triggers for long-term credit: credit funding - the amount of long-term credit funding; target credit funding - the amount of long-term target credit funding; ${ }^{6}$ triggers for means of payment; $\sigma^{2}$ - The dispersion of annual cash flows, UAH.; $\beta$ - costs of converting money into securities, UAH; $M C \frac{\mathrm{opt}}{\mathrm{min}}$ - this is the optimal limit, that that will allow sustaining the liquidity and protect funds from inflation; $M C \frac{\max }{\min }-u p p e r$ bound limit of the financial resource; $\mathrm{MC} \frac{\mathrm{mim}}{-}-$ lower bound limit of the financial resource

Source: formed by the author based on (Maslyhan, 2016, pp. 408-413). 
When the lower possible bound is reached, securities procured in earlier periods to be implemented in an amount, sufficient to replenishment of the financial resources to the initial value. A similar algorithm is used in the presence of monetary deposits. Thus, triggers for means of payment (according to the MillerOrr model), will be based on calculating band of fluctuation of the financial resources balance between the maximum and minimum values (Maslyhan, 2016, pp. 408-413).

The process of methodological algorithmization of technological sustainability should be ensured in the in practice quality of tourism products or services (since this is the ultimate goal technological upgrading of cluster actors).

It is the most appropriate use of process control of the basic characteristics of quality of tourist product or services. At the same time, is expedient for choosing the Fishbone (or Ishikawa) diagram. This method identifies the quality problems and distributes them to key categories that affecting the services or product profile. In so doing the ideal profile forms an attractor's fixed point. This is, in our view, will allow finding ideal solutions problems of compliance services or product of cluster actors of the established requirements.

The process of methodological algorithmization of technological sustainability should be based on identified of key categories of process quality and the Ishikawa diagrams.

The reference state of key categories of process quality should be determined on the basis of the "house of quality" method adapted to the needs of the cluster actors. This method is a possible element of contents differentiation (based on a system approach to contents at all stages of the life cycle) of the technological quality based on recognizing the needs of the consumer of tourist product or services.

Within the above context, the identification of subjective perceptions of consumers about the quality of tourist products or services (produced in the cluster). Also should be ensured a set of categories of their process quality should be formed with the determination of their reference state (Lifits, Zhukova and Nikolaeva, 2014). This process is appropriate to conduct in the following order (Lifits, Zhukova and Nikolaeva, 2014):

1) the consumers' claims study (via questionnaire) and indication importance of such consumers' claims across of the key categories of Fishbone process quality;

2) Define reference state or each key category of process quality. This is done through the characteristics of similar tourist services or products $(\beta)$, produced in or outside the cluster. That is assuming, of course, that demand for such products and services exist;

3) Construct "Quality House" matrix. The process involves for interrelations identification between the consumers' requirements (by quality categories) and the reference state of the services or products $(\beta)$, produced in the cluster. In some situations, may be using markers of ties (M), from the perspective of: strong ties - S; middle ties - $\mathrm{N}$; weak middle ties W.

4) Whenever a significant deviation from the standard arose it is advisable to identify problems of increasing the technological sustainability of cluster actors. The same specificity should exist at low assessments of competitive position of cluster actors (by the key categories of quality of a tourist product or service). For example, these actors may not always have the necessary specialists, equipment, techniques of service delivery. But that should be to meet the requirements of consumers and achieve a standard of quality. That is why additional column of "The problems of achievement of the standard of quality and meeting the requirements of consumer" can be useful complement to matrix "house of quality". The assessment can be carried out based on an estimate scale, with markers of quality problems impact from the perspective of: 
strong impact $-\mathrm{S}$; middle impact $-\mathrm{N}$; minor impact - W.

\section{Conclusions.}

It is necessary for the formation of methodological algorithmization for optimizing the technological quality of the tourist product or services in order to maintain a high level of technological sustainability of cluster actors. This will be facilitated by constant monitoring of the level of process quality of the tourist product or service. The basis of such monitoring should be the comparison process of the quality of the tourist product or service of the cluster actors and its competitors. Monitoring of the technological quality level of product or service will help to understand how to achieve its standard.

The methodological algorithms operation of sustained functioning of cluster's actors in the area of tourism and recreation should aim at determining the values of the processing characteristics of the manufacturing process (own and competitors) and identify the directions for their improvement. Individual measurement indicators correspond to each processing characteristics of the manufacturing process.

Therefore, these characteristics should be assessed into a comparable form. Namely it based on rating scales and taking into account the mutual influence on the actual competitive rating. To reveal and calculate the mutual influence of processing characteristics (on each other and on the actual assessments of competitive position), as a setting for quality home, additional columns of the roof type is formed.

In doing so, rapprochement the process quality of the tourist product or services and its ideals can provide the identification of the most important technological characteristics. The identification process can be done by multiplying the average rating (of each characteristic) by the rating of its weights to the consumer.

\section{References}

Bodarieva, T. I. and Shirinian, L. V. (2018), "Manages the financial stability of enterprises”, Prychornomorski ekonomichni studii, no. 35. pp. 85-90.

Chala, N. D. (2012), "Development of innovative clusters as the basic strategy of modernization of regions", Klastery yak instrument rehionalnoho rozvytku [Clusters as a tool for regional development], Materialy naukovo-praktychnoho seminaru [Materials of the scientific and practical seminar], Feodosia, Ukraine, July 16-20, 2012, pp. 94-98.

Chukhno, A. A. (2010), Ekonomichna teoriia [Economic theory], vol. 2., DNNU AFU, Kyiv, Ukraine, 628 p.

Chykarenko, I. A. (2012), "Formation of cluster structures at the municipal level: Institutional and organizational aspect", Klastery yak instrument rehionalnoho rozvytku [Clusters as a tool for regional development], Materialy naukovo-praktychnoho seminaru [Materials of the scientific and practical seminar], Feodosia, Ukraine, July 16-20, 2012, pp. 99-103.

Dovba, I. V. and Soima, S. Iu. (2016), "The features of optimization for controlling business processes in the enterprise and how to improve them", Ekonomika i suspilstvo, no. 6, pp. 130-133.

Dudar, A. A. and Vakulchyk, O. M. (2018), "Inventory and optimization of capital structure in order to improve the financial stability of enterprises", Molodyi vchenyi, no. 1(53), pp. 878-882.

Fesun, A. S. (2015), "The development of the adaptogenic instruments variety of sources of finance of building companies with new logic, financial transactions to programme products”, Innovatsiina ekonomika, no. 56, pp. 104-108.

Klepikova, O. A. and Silvestrova, Yu. S. (2015), "Modelling the expenditure of enterprises subject to the limitations", Naukovyi visnyk Khersonskoho derzhavnoho universytetu, vol. 11, no. 1, pp. 167-171.

Kmit, V. M. and Dziurii, O. I. (2016), "Optimization and minimization taxes within the system of financial management economic agents ”, Molodyi vchenyi, no. 1(28), pp. 65-69.

Lifits, I. M., Zhukova, F. A. and Nikolaeva, M. A. (2014), Tovarnyi menedzhment [Commodity management], Yurait, Moscow, Russia, 405 p.

Maslyhan, O. O. (2016), "The role economic-mathematical modeling in increasing the effectiveness of current assets management: tourism enterprise case study”, Aktualni problemy ekonomiky, no. 4, pp. 408-415. 
Orlova, A. A. and Buhaieva, M. V. (2017), "Experience of formation and development cluster in post-socialist countries in the context of the national security of Ukraine ", Efektyvna ekonomika, [Online], no. 11, available at: http://www.economy.nayka.com.ua/?op=1\&z=5892 (Accessed 6 January 2019).

Shcherbak, H. V. (2018), “The tractor models of the concept are evaluated in the modern English-speaking discourse”, Zakarpatski filolohichni studii, vol. 4, no. 2, pp. 31-35.

Sheludko, V. M. (2015), Finansovyi rynok [Financial market], vol. 2, Znannia, Kyiv, Ukraine, 535 p.

Yushchenko, N. L. and Kuslii, I. P. (2015) "Models and software products address the problem of activities are self-sustaining”, Naukovyi visnyk Polissia, no. (4), pp. 76-86.

Цей твір ліцензовано на умовах Ліцензії Creative Commons «/з Зазначенням Авторства = Некомериійна 4.0 Міжнародна» (CC BY-NC 4.0). This is an open access journal and all published articles are licensed under a Creative Commons "Attribution-NonCommercial 4.0 International" (CC BY-NC 4.0). 